Pacific Northwest Energy Related

Regional Assessment Program

\title{
Energy Policy and Public Acceptance: Current and Future Directions
}

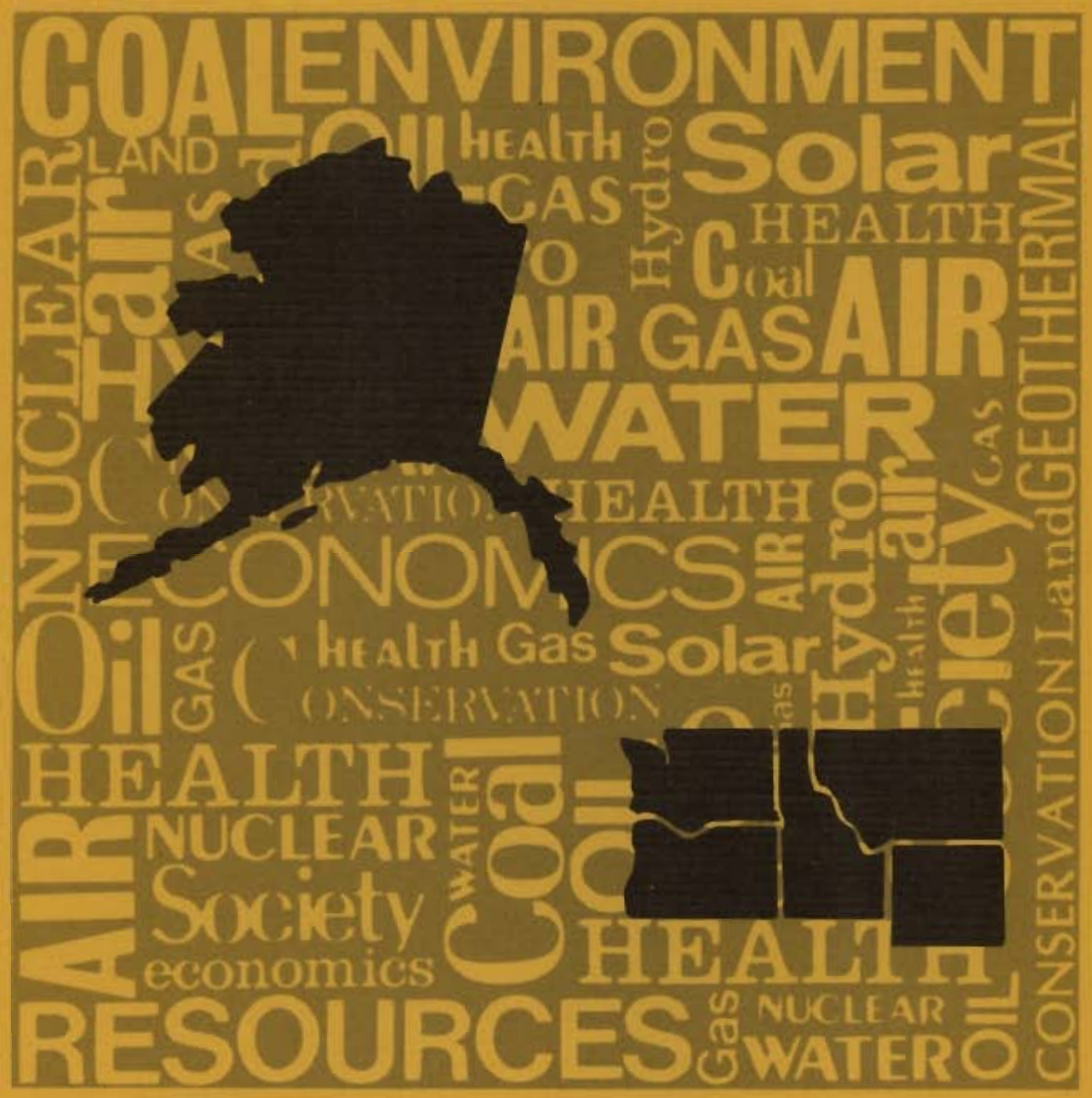

May 1977

Prepared for the U.S. Energy

Research and Development Administration

under contract AT(45-1): 1830 


\section{NOTICE}

This report was prepared as an account of work sponsored by the United States Government. Neither the United States nor the Energy Research and Development Administration, nor any of their employees, nor any of their contractors, subcontractors, or their employees, makes any warranty, express or implied, or assumes any legal liability or responsibility for the accuracy, completeness or usefuiness of any information, apparatus, product or process disclosed, or represents that its use would not infringe privately owned rights.

PACIFIC NORTHWEST LABORATORY

operated by

BATTELLE

for the

ENERCY RESEARCH AND DEVELOPMENT ADMINISTRATION

Under Contract EY-76-C-06-1830.

Printed in the United States of America

Available from

National Technical Information Service

U.S. Department of Commerce

5285 Port Royal Road

Springfield, Virginia 22151

Price: Printed Copy S___ Microfiche $\$ 33.00$

$\begin{array}{lc}\text { - Pages } & \text { Selling Price } \\ 001-025 & \$ 4.50 \\ 026-050 & \$ 5.00 \\ 051-075 & \$ 5.50 \\ 076-100 & \$ 6.00 \\ 101-125 & \$ 6.50 \\ 126-150 & \$ 7.00 \\ 151-175 & \$ 7.75 \\ 176-200 & \$ 8.50 \\ 201-225 & \$ 8.75 \\ 226-250 & \$ 9.00 \\ 251-275 & \$ 10.00 \\ 275-300 & \$ 10.25\end{array}$




\section{5}

ENERGY POLICY AND PUBLIC ACCEPTANCE: CURRENT AND FUTURE DIRECTIONS

by

M.G. Curry

M. Greene

M.K. Lindell

May 1977

Battelle Memorial Institute Human Affairs Research Centers 400041 st Street N.E. Seattle, WA 98105 


\section{CONTENTS}

INTRODUCTION

OVERVIEW OF PUBLIC INVOLVEMENT.$\quad \cdot \quad \cdot \quad \cdot \quad \cdot \quad \cdot \quad \cdot \quad \cdot \quad \cdot \quad \cdot \quad \cdot 2$

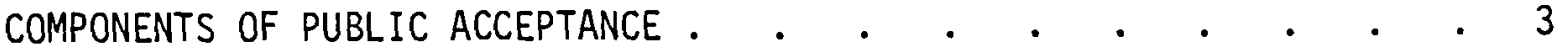

PUBLIC ATTITUDES.$\quad$ •

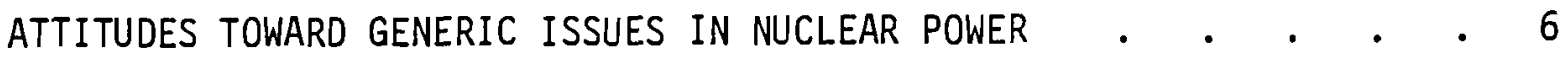

ATTITUDES TOWARD SPECIFIC NUCLEAR POWER PLANT SITINGS $\cdot \cdot \cdot \cdot \quad \cdot 7$

ATTITUDES TOWARD COAL DEVELOPMENT.$\quad \cdot \quad \cdot \quad \cdot \quad \cdot \quad \cdot \quad \cdot \quad \cdot \quad \cdot 7$

ATTITUDES TOWARD GEOTHERMAL DEVELOPMENT

PUBLIC ACTIONS AND BEHAVIOR

CONTENT AND SITE-SPECIFIC STUDIES.$\quad \cdot \quad \cdot \quad \cdot \quad \cdot \quad \cdot \quad \cdot \quad \cdot \quad \cdot 10$

DESCRIPTIONS IN THE POPULAR PRESS . . . . . . . . . . 12

CITIZEN INVOLVEMENT IN RESOURCE DECISION-MAKING

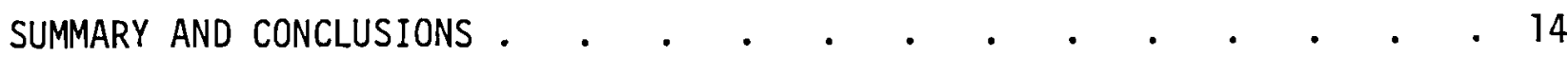

REFERENCES • . . . . . . . . . . . . . . . 17 
ENERGY POLICY AND PUBLIC ACCEPTANCE:

CURRENT AND FUTURE DIRECTIONS

\section{INTRODUCTION}

The feasibility of any suggested energy plan for the Pacific Northwest is determined not only by the economic and technical characteristics of the energy option but also by the public's acceptance of the options. The degree of public acceptance, ranging from strong support to firm opposition, can significantly affect the implementation of an energy policy or energy development plan. Although the past several years have seen public acceptance increasingly acknowledged as an important factor in energy policy and decision-making, insufficient effort has been given to the analysis of the determinants and consequences of public attitudes toward energy policies.

Because of the substantial influence that public acceptance may have on energy policy, there is a clear need to systematically examine the role of public acceptance in the energy decision-making process. In response to that need, this report examines two major aspects of the problem. The first step is to identify the issues central to public attitudes toward energy policy options; the second is to identify the techniques or types of behavior that have been used by the public to support or resist such policy options. The analysis of these two aspects of public acceptance will be instrumental to a more complete understanding of the nature and extent of public acceptance, its role in past energy development activities, and its implications for the future. 


\section{OVERVIEW OF PUBLIC INVOLVEMENT}

Public attitudes and public expression of acceptance or nonacceptance can have an impact at any of several stages of policy formulation and implementation. And although there have been and continue to be some public officials who feel that ignoring or minimizing public concerns and involvement in policy formulation and implementation is the best strategy to follow, their approach is weakened by increasing evidence that adverse public attitudes can delay projects significantly and can drastically increase project costs. (See Ref. 1 for a discussion of the hidden costs of project delays).

Unfortunately, public officials commonly still exclude citizens from the early stages of policy development because citizen issue awareness is low and citizens' groups are not effectively organized. However, this situation is changing as public officials realize the ultimate costs that can result from such treatment of citizens. At later stages in the policy process citizens do have access to certain forums in which they can raise objections to what they consider undesirable aspects of development. These means, which include review of environmental impact statements, court action, and the initiative process, can have both direct and indirect effects.

Direct effects are the most commonly discussed effects of citizen intervention in the energy policy process. The nuclear safeguards initiatives recently put forth for voter consideration in several states reflected an attempt to influence directly the course of energy development by imposing constraints upon various aspects of nuclear facilities. Other technologies are also susceptible to citizen intervention. Lack of public acceptance of proposed energy options may force changes in the design, size, location, or timing of a proposed option to reduce its magnitude or mitigate its impacts. This, in turn, can add to the economic cost of that energy option. (Retrofit of stack scrubbers for fossil-fueled power plants is a good example of the latter.)

Indirect effects, though less commonly recognized, are equally important to consider. For example, the public's failure to accept a particular energy 
technology may produce investor uncertainties in that region, which in turn can affect capital investments in energy technologies and energy-intensive industries. Lack of acceptance could indirectly lead to increased economic costs associated with implementing the energy option. In short, citizens can have substantial effects upon the feasibility and cost of energy development options through indirect economic means in addition to their more direct involvement with executive or legislative bodies at the federal, state, and local levels.

An important point is that availability of citizen involvement mechanisms is not the same as utilization. Not all means of access are used when a group of citizens find themselves opposed to an energy development project. Several factors determine the method of attempted influence, and these vary with the nature of the problem. Rather than attempt to develop a generic model, we will present an overview of the implications of public attitudes and acceptance in technology-specific situations.

\section{COMPONENTS OF PUBLIC ACCEPTANCE}

Public acceptance may be viewed as having both attitudinal and behavioral components. The attitudinal component consists of citizens' evaluations (explicit or implicit) of an issue. The behavioral component consists of the actions people take concerning the issues. Attitudes and behavior are related, but the exact nature of the relationship is not simple. Attitude theorists generally agree that each attitude is related to many different kinds of potential actions and that each act is determined by many different attitudes. (2)

Many past and current studies of public acceptance have focused on the public's attitudes toward energy and other resource policy arenas. Through analyses of demographic and psychological variables the attitude surveys have sought to explain these attitudes and to predict acceptance.

The case studies, on the other hand, have been oriented toward retrospective reports of particular incidents. These accounts of siting decisions have illuminated ways in which public acceptance was lost (if it existed in the first place). 
Both the attitude surveys and the case studies can contribute valuable insights to our understanding of the problems of public acceptance of energy policy. Unfortunately, work within each of these perspectives has not taken advantage of the achievements of the other. The fact that attitudes and behavior are not perfectly related implies that attitude surveys as they are currently implemented will not suffice. Since relationships between attitude and behavior, however imperfect, do exist, case studies alone are also insufficient.

Only through an integration of these two approaches will we gain an understanding of the problem. We recognize that this integrative process will not be simple; therefore, our aim in this report is to collect what we consider to be the most relevant work available from each of these perspectives. We have made a special effort to locate and document studies that provide accounts of ways in which the public has played an active role in energy decision-making, as well as articles on attitudes related to energy and resource policy.

The discussion to follow is oriented primarily toward issues of socioeconomic and environmental impact, since these are the issues that have been most emphasized in the debates over energy policy. The intensity of these debates has been due largely to the fact that socioeconomic and environmental impacts are external to the private developer and are by definition matters of public policy. Furthermore, they are the factors about which there exists the most uncertainty.

The articles reviewed here are divided into two groups. The first classification involves the distinction between attitude surveys and case studies. The second classification concerns whether the issues at hand are generic or site-specific in nature. For the attitude studies, the classification divides those surveys concerned with general issues of energy policy from those focusing upon the impacts of a particular technology upon a specific locale. For the case studies, this distinction separates the studies involving national intervenors from the reports on local resistance to siting decisions. 
The majority of the case studies and articles reviewed focus on nuclear and coal energy facility siting decisions, because these are what much of the current debate concerns. A few studies are related to water resources development where many of the same siting issues arise. 


\section{PUBLIC ATTITUDES}

\section{ATTITUDES TOWARD GENERIC ISSUES IN NUCLEAR POWER}

Three studies were identified that focus on attitudes toward the development of nuclear power and related activities. Rappoport reported a survey of attitudes and behavior regarding energy savings that also asked about citizens' perceptions of the most serious problems in the development and construction of nuclear power plants. (3) Waste disposal, radiation discharge, nuclear accidents, and thermal pollution were the issues of major concern to these respondents. Interestingly, while 65\% favored nuclear power as an energy source, only $49 \%$ would favor having a plant located within 20 miles of their home. This point suggests potential conflicts over the siting of nuclear facilities, which is borne out in the review of case studies.

A recent Battelle study ${ }^{(4)}$ on public values toward nuclear waste disposal also identifies several issues of major public concern. The results of this study show that substantial differences exist between nuclear technologists and environmentalists in their beliefs about nuclear power. Environmentalists, for example, see nuclear waste disposal as a much more serious problem, express more reservations about the safety of nuclear power, and forecast less need for increased production of electric power in general and nuclear power in particular than do nuclear technologists. The environmentalists are more optimistic about the near-term feasibility of alternatives such as solar and geothermal power and conservation.

A poll conducted by Harris and Associates (5) indicated substantial concern about radioactive waste materials. Other issues named were plant explosions, thermal pollution, sabotage, polluting fumes, and plutonium theft. Advantages of nuclear power that were cited included lower cost (than oi1), assured supply, and overall lower level of environmental pollution. Respondents in a national probability sample favored the building of nuclear power plants by a substantial margin (63\% in favor of, $19 \%$ against). 


\section{ATTITUDES TOWARD SPECIFIC NUCLEAR POWER PLANT SITINGS}

The Harris and Associates study ${ }^{(5)}$ also reported the results of surveys of residents in three communities where nuclear power plants were located. The authors of the report noted that a higher percentage of the respondents in these communities classified the plants as "very safe" (48\% in San Onofre, California; 33\% in Morris, I1linois; $25 \%$ in Indian Point, New York--an average of $35 \%$ for all three communities) than did members of the national probability sample (26\% nationwide) who were also asked the same question. In short, those who live close to nuclear power plants are more likely to regard them as safe.

Schuller et al. ${ }^{(6)}$ report another local siting survey conducted during the preconstruction phase. Their survey of attitudes toward a proposed nuclear power plant in Hartsville, Kentucky, found that a majority of people favored the plant. The major reasons for opposing the plant, or major concerns about the plant, centered around community disruption and safety (radiation hazards, plant safety, security, and ecological impact).

\section{ATTITUDES TOWARD COAL DEVELOPMENT}

Recent attitude studies on coal development focus on the Rocky Mountain and northern Great Plains states where a coal boom is taking place. Many of the studies focus on how the mining and the resulting coal boom affect the quality of life in the small communities, rather than on direct public attitudes of acceptance or nonacceptance of the technology. Those studies that do have information on public acceptance and nonacceptance of coal development generally focus on the first stage of development--the mining--rather than the generating plants.

Jobes and Parsons $(7)$ conducted a survey in Montana to explore perceptions and attitudes toward coal development and land use planning. Coal-related concerns of the residents generally centered around pollution, with many people expressing the view that plants should meet pollution standards or shut down. Residents also expressed concern about the loss of recreational lands to coal development. Rural dwellers, in particular, resisted the idea of coal development, expressing apprehension regarding outsiders. 
Two related studies $(8,9)$ of the social impacts of coal development in eastern Montana and northeastern Wyoming included data from a survey of the reactions of local people to coal development. While a few people (mostly ranchers) were totally opposed to coal development, most people showed anxiety over the impact of coal development on the character of the area and their quality of life. The major issues were damage to or destruction of agricultural land as a resource, competition for water resources, and air pollution. These studies also point out some actions that have been taken by the local public. For example, ranchers have set up organizations (e.g., the Powder River Basin Resource Council) in both states in an attempt to slow down or at least control coal development. Particular concerns of these organizations are reclamation and water development for industry.

Blevin et al. (10) found in a survey of Campbell County, Wyoming, that residents' attitudes toward coal development were generally favorable. However, there was substantial concern about the effects of strip mining on the physical environment, and, in particular, the possibilities for reclamation.

\section{ATTITUDES TOWARD GEOTHERMAL DEVELOPMENT}

There have been some preliminary attempts to measure public attitudes toward geothermal development, particularly the attitudes of residents immediately impacted by such development. Volintine and Weres (11) analyzed public opinion in the Cobb Valley of Lake County, California, where geothermal development has been proposed. Their findings indicated that two-thirds of the county-wide population supported development. One-third of the Cobb Valley people were undecided or had mixed feelings. These researchers also found that support for and opposition to geothermal development correlated most highiy with respondents' perceptions of environmental impacts, their expectation of economic benefits in the form of increased job opportunities and tax revenues, and the size of their 1 and holdings. $(11, p .3)$ 
By basing their work on case studies, several authors have analyzed types of public activities related to acceptance of energy and environmental decision-making processes. Fanning ${ }^{(12)}$ analyzes mechanisms used by the public to influence environmental decision-making. He focuses on federal legislation-most notably the National Environmental Policy Act, the Freedom of Information Act, and the Administrative Procedures Act--to show how these acts provide mechanisms for citizens to become involved actively in environmental decisionmaking. He illustrates the actual mechanisms through case studies and discusses such mechanisms as media pressure, letters to industry and legislators, lobbying, testimony at hearings, political activities (e.g., initiatives), educational and research activities (informing the public, contact with responsible agencies) direct negotiation, arbitration, and lawsuits. As Fanning points out, the mechanisms vary with the type of issue and with the type of citizen group involved. For example, national environmental groups often lobby to influence environmental and energy legislation and also use litigation as well as educational techniques to influence decisions.

An Atomic Energy Commission report to the Federal Energy Administration entitled Public Acceptance of Civil Nuclear Power Systems ${ }^{(13)}$ focuses specifically on acceptance behaviors. Though much of this report is devoted to recommendations for principles and federal actions to increase public acceptance, the authors also identify the issues that the public perceives as constraints to nuclear power development and their degree of concern. These issues include:

- High Concern: power plant design, location and operation, decision process

- High to Medium Concern: waste handling and disposal, decision process materials, safeguards

- Medium Concern: extraction, transportation, fabrication, and processing

- Low Concern: transmission of power except when local concerns become aroused 
This report also analyzes patterns of conflict, describing the adversary process of challenges by nontechnical persons, backed by scientist critics who testify in construction and operations permit processes. It provides a comprehensive though biased overview of public acceptance as it has been enacted in the nuclear case.

\section{CONTENT AND SITE-SPECIFIC STUDIES}

Most studies of public behavior are narrative descriptions based upon the researcher's perceptions and interpretation of specific events (often obtained through talking to some of the involved parties). Therefore, it is more difficult to make comparisons from one case study to the next. We have attempted to give an overview of the findings of several representative case studies, as well as to mention other sources of information regarding public acceptancerelated behavior.

A symposium on participation in resource decision-making (14-16) provides several case studies of citizen actions in public facility siting and resource policy processes. These studies also analyze the interaction of community participants with policy-making organizations. Wilkinson (14) describes an environmental conflict (the building of an expressway) where the public was excluded in a formal way from the decision-making. The resulting problems led to the conclusion that three basic changes were needed: the formulation of viable public participation programs, the creation of a broad policy of developing constructive public participation, and a change in attitudes toward the involvement of citizens in local decision-making. Wolpert presents a conceptual model of how public facility (urban expressways, airports, and urban renewal) decisions are actually made. The model is a "cynically based description," pointing out that those adversely affected are stimulated to political activism, and full compensation also has its costs. Wood $(16, p .157)$ also presents a case for further input of public views into the decision-making process, arguing that "the fact that threats are used as a major form of communication where no provision for citizens' views are made indicates that some form of public input would at least mitigate conflict." 
Lewis (17) provides an environmentalist's view of citizens' roles in the nuclear power decision-making process. Citing most of the major power plant siting cases, he notes that citizens have been most successful when stressing environmental protection (thermal pollution) and safety issues. He also documents the techniques and resulting influence yielded by intervenors in the hearing processes, as he interprets them. A similar analysis (18) states that citizens become actively involved in nuclear power cases for three reasons: plant safety and minimizing impacts, concern that public information be upgraded, and attempts to delay or stop the plant. Al1 these concerns are manifestations of public acceptance. Several other case studies of nuclear power plant controversies ${ }^{(19-23)}$ further analyze in detail the issues that motivate citizens to act; where and how in the decision process citizens seek to influence policies or plans; and the results of these citizen actions.

Nelkin $(19,23)$ provides an in-depth analysis of the role of the public, and particularly of local scientific experts, in the nuclear power plant siting controversy at Cayuga Lake near Ithaca, New York. The major issues over the proposed plant site centered around the effects of thermal pollution on the ecology of the lake and its consequences for uses of the lake (i.e., recreation). Nelkin focuses primarily on the techniques used by the scientific community acting as advocates for the local ad-hoc citizens' group. The scientists testified at hearings and wrote testimony, thus providing local citizens with increased information and influence in the siting process.

Kaufman ${ }^{(22)}$ briefly reviews several nuclear power plant siting cases in the state of New York in which the public sought to influence plant siting decisions. The issues on which public acceptance centered were environmental impact and reactor safety. Public efforts to influence the siting decision process all revolved around filing of court suits, most of which made claims of insufficient safety mechanisms and insufficient discussion of alternative means to meet energy needs.

Gendl in ${ }^{(20)}$ describes a citizen intervention effort in an area of Michigan where a new nuclear plant was being proposed. At issue was the pollution of Lake Michigan and fear that the adjacent shoreline would be 
ruined. The citizens requested a hearing with a petition containing 35,000 signatures and delayed the issuance of the operating license until the Atomic Energy Commission dealt with their concerns. They were able, through their organized efforts, to raise thermal and radioactive pollution standards to well above federal standards.

Metzger (21) presents a review of the Atomic Energy Commission's decisionmaking process, which he believes provided little opportunity for citizen involvement. Metzger states that the courts have provided the only means for citizens to influence nuclear power siting decisions, and it is a slow, expensive and inefficient process.

\section{DESCRIPTIONS IN THE POPULAR PRESS}

Aside from the nuclear power plant siting area, little formalized research was uncovered pertaining to public acceptance behavior in other energy technology policy-making processes. This is not an indication that public acceptance has not influenced decisions regarding coal, oil, gas, geothermal, solar, and hydroelectric power policy and developments. In fact, various articles, particularly in environmental and conservation publications, illustrate the active role that public acceptance has had on numerous energy-related issues. However, because these articles often are not in-depth studies of public acceptance, it is difficult to ascertain the specific role that the public has had as one of several factors in the decision process.

Mitche11 ${ }^{(24)}$ examines the actions of local and national environmental groups at regional hearings held on the Outer Continental Shelf Draft Environmental Impact Statement for oil exploration. (Testimony, written opposition statements, and lawsuits were cited as public actions.) Gilbert ${ }^{(25)}$ describes the role of concerned agencies, firms, and locals in the Alaska oil pipeline controversy. Finally, Josephy ${ }^{(26)}$ provides an in-depth analysis of the Kaiparowitts power plant decision process from an environmentalist's point of view. In addition to these studies and articles, many more accounts of citizens' responses to energy and environmental policy or proposed actions were discovered in the popular press. In many of these cases, local affected 
residents and/or environmental groups took active roles; thus they demonstrated their acceptance or nonacceptance of specific points and suggested changes in policies and plans that would increase the public's acceptability of the proposed project.

\section{CITIZEN INVOLVEMENT IN RESOURCE DECISION-MAKING}

There is a significant body of literature that focuses on citizen participation in public decision-making. Most relevant to this report are the articles and studies that analyze or describe citizen participation in resource- and energy-related policies and projects. The Corps of Engineers (27) and other general water resource-related projects ${ }^{(28)}$ have been the object of much public interest or concern. Consequently, citizen involvement has, to a certain extent, been formally incorporated into the planning processes of these agencies. While formally organized and agency-initiated citizen involvement programs may occur as a result of perceived or overt citizen actions and concerns, this does not assure that such programs address those issues of paramount importance to the citizens, or that they allow citizens to exercise the role they prefer at the phase of the decision-making process they wish to influence. Because of the formal organization of citizen involvement into bureaucratic processes, the actual mechanisms for effectuating involvement will differ among various citizen-initiated actions.

Although the whole field of citizen involvement is an important element in a full consideration of public acceptance, it is primarily concerned with how to provide ways for citizens to obtain information and to give feedback regarding agency proposals and plans. This literature generally does not focus on how citizens act on their own initiative to voice their acceptance or nonacceptance of particular policies and programs. In light of this different bent of the citizen involvement literature concerning energy issues (e.g., hydroelectric power), we have omitted it from this discussion of public acceptance. For further discussion of citizen participation, the interested reader is referred to Bishop $(27)$ for a theoretical overview and to Onibokun and Curry ${ }^{(29)}$ for a recent example. 


\section{SUMMARY AND CONCLUSIONS}

As this brief review of literature concerning the attitudinal and behavjoral aspects of public acceptance indicates, the public actively reveals its acceptance or nonacceptance of energy-related policies in a variety of ways. While a wide range of issues are involved in the public's judgment of energy policies, it becomes apparent that several major issues are consistently associated with specific energy technologies. Similarly, various types of groups are more likely than others to engage in certain behaviors or actively seek to influence the decision process (e.g., ranchers forming organizations to control coal development in the Rocky Mountain area, Friends of the Earth filing lawsuits over noncompliance with environmental legislation).

This documentation of several ways in which the public has expressed acceptance in energy and environmental decision-making is a preliminary step in learning more about the role of public acceptance in this process. Often public acceptance of energy-related decisions--or lack of it--is viewed as an obstacle to be overcome. We would rather view it as an aid to more effective policies that are consistent with public values and needs.

While much is already known about public attitudes toward various aspects of energy policy making and development, less has been discovered about the public actions aspect of public acceptance. We currently lack a systematic and comprehensive approach to understanding public acceptance and the issues central to such acceptance. We also lack a precise method for incorporating public acceptance into the energy decision-making process.

We propose that a systematic approach to public acceptance can be developed to provide energy decision-makers with parameters of public acceptance for the various energy technologies and issues. As an example, Table 1 shows factors involved in the public's attitudes and behavior toward implementing several energy technologies. Such parameters could be instrumental in making the decision-making process more effective by incorporating public values into the formulation of alternatives before formal public input is required or usually sought. This framework must be part of a dynamic ongoing monitoring process, so as to retain its relevance by reflecting changes in public 


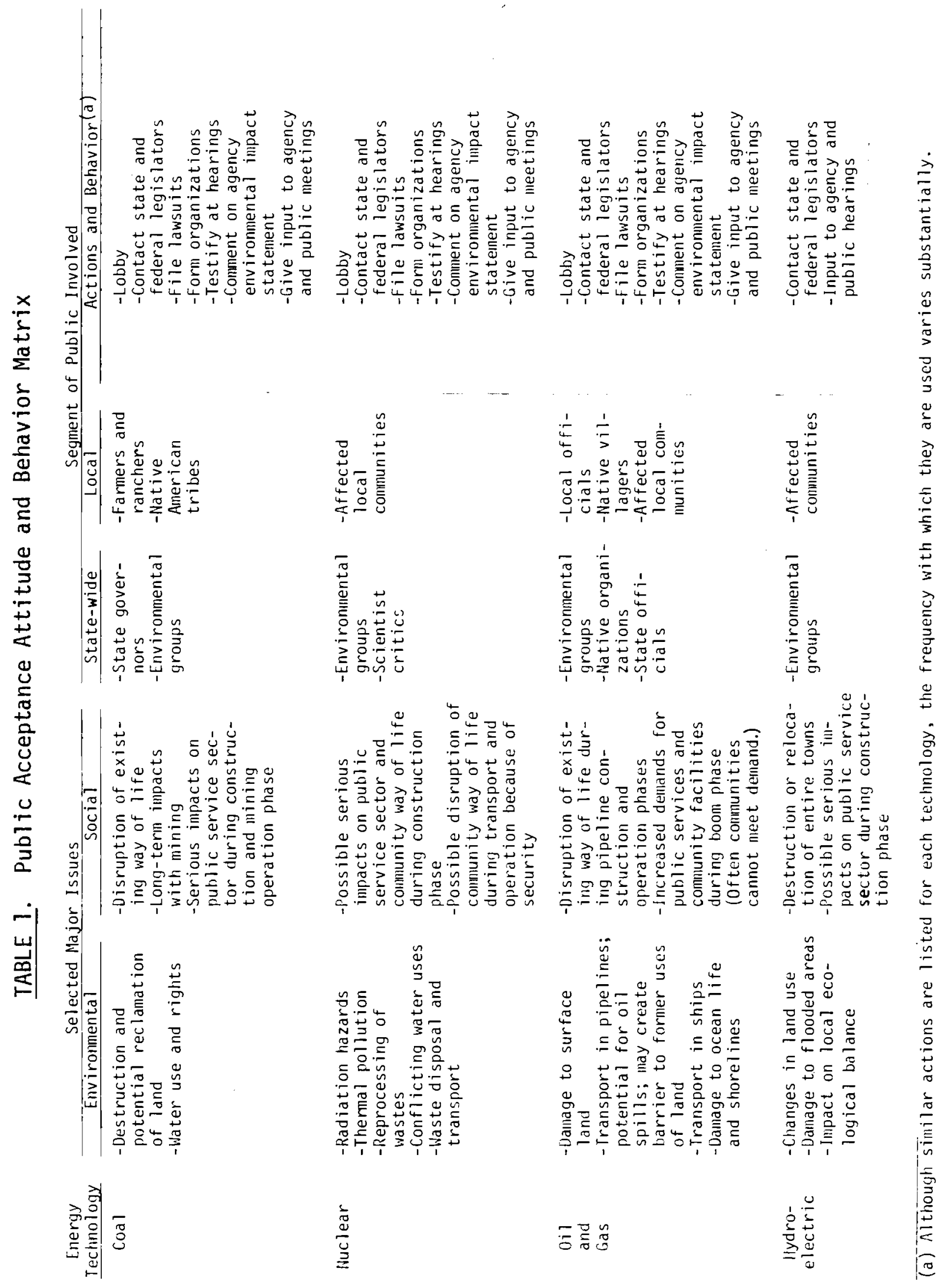


concerns. The present review of available literature should be considered only a preliminary step in developing this systematic approach. It should be followed by a comprehensive analysis of representative case studies of energy decision-making in which public acceptance has had an influence on the process and the eventual policy.

In addition, future work needs to address the connection between attitudes toward energy technologies and attitudes toward technology in general. Some promising work on the latter subject has been published recently by LaPorte and Metlay. ${ }^{(30)}$ One key finding was that approval of a technology is influenced by one's certainty about its advantages or disadvantages. Other important work on response to technology was reported by Goodman and Clary, (31) who studied responses to airport noise. They noted that evaluation of the success of a noise abatement program was related to perception of the commitment of the airport management to eventual solution of the problem. This study is not the only one in which the perceived intent of the decision-makers surfaces as an important consideration in the area of public acceptability. Heberlein ${ }^{(32)}$ has suggested that environmental managers are increasingly seen as having control over alternative actions for manaing adverse impacts and thus are being held increasingly responsible for their actions. This conclusion, which is consistent with the other studies we have seen, suggests that citizen participation strategies will become increasingly necessary in the future. Through these techniques, energy decisionmakers can better explain to the public the goals and constraints that shape their choices. In turn, the decision-makers will be better able to ascertain the values that determine the preferences of the public. 


\section{REFERENCES}

1. A. Kaufman, "Beauty and the Beast: The Siting Dilemma in New York State," Energy Policy 1: December 1973.

2. M. Rokeach, Beliefs, Attitudes and Values: A Theory of Organization and Change, Jossey-Bass, San Francisco, 1970.

3. M. Rappoport et a1., General Public Attitudes and Behavior Regarding Energy Saving, Highi ight Report, vol. IX, Opinion Research Corporation, Apri1 1975.

4. W. S. Maynard, S. M. Nealey, J. A. Hebert, and M. K. Lindell, Public Values Associated with Nuclear Waste Disposal, BNWL-1997, Battelle Institute, Seattle, WA, 1976.

5. L. Harris and Associates, A Survey of Public and Leadership Attitudes Toward Nuclear Power Development in the United States.

6. C. R. Schuller et al., Citizens Views About the Proposed Hartsville Nuclear Power Plant: A Preliminary Report of Potential Social Impacts, ORNL/RUS-3, Oak Ridge National Laboratory, Oak Ridge, TN, 1975.

7. C. Jobes and G. Parsons, Satisfaction, Coal Development and Land Use Planning: A Report of Attitudes Held by Residents of the Decker-Birney Study Area, submitted to the Montana Energy Advisory Counci1, Apri] 30, 1975.

8. Community Service Program (formerly Institute for Social Science Research), University of Montana, A Comparative Case Study of the Impact of Coal Development on the Way of Life of People in the Coal Areas of Eastern Montana and Northeastern Wyoming, final report, June 30, 1974.

9. Community Service Program, University of Montana, Final Report: A Study of Social Impact of Coal Development in the Decker-Birney-Ashland Area, prepared for Montana Energy Advisory Council, May 31, 1975.

10. A. Blevins, J. Thompson, and C. Ellis, "Social Impact Analysis of Campbel1 County, Wyoming," prepared for Wyoming Environmental Institute under contract with Atlantic Richfield Company, December 1974.

11. L. Vollintine and 0 . Weres, Public Opinion in Cobb Valley Concerning Geothermal Development in Lake County, California, Lawrence Berkeley Laboratory, June 1976 .

12. 0. Fanning, Man and His Environment: Citizen Action, Harper and Row, New York, $19 \overline{75 .}$ 
13. Federal Energy Administration, Project Independence Blueprint, Final Task Force Report, Appendix IX, "Public Acceptance of Civil Nuclear Power Systems," November 1974.

14. P. WiTkinson, "Public Participation in Environmental Management: A Case Study," Natural Resources Journal 16: 117-135, January 1976.

15. J. Wolpert, "Regressive Siting of Public Facilities," Natural Resources Journal 16: 103-115, January 1976.

16. Colin J. B. Wood, "Conflict in Resource Management and the Use of Threat: The Goldstream Controversy," Natural Resources Journal 16: 137-158, January 1976.

17. R. S. Lewis, The Nuclear Power Rebellion: Citizens vs the Atomic Industrial Establ ishment, The Viking Press, New York, 1972.

18. S. Ebbin and R. Kaspar, Citizen Groups and the Nuclear Power Controversy: Uses of Scientific and Technological Information, the MIT Press, Cambridge, MA, 1974.

19. D. Nelkin, Nuclear Power and Its Critics: The Cayuga Lake Controversy, Cornell University Press, Ithaca, NY, 1971.

20. F. Gendlin, "The Palisades Protest: A Pattern of Citizen Intervention," pp. 53-56 in The Bulletin of the Atomic Scientists, November 1971.

21. H. Metzger, The Atomic Establishment, Simon and Schuster, New York, 1972.

22. A. Kaufman, "Beauty and the Beast: The Siting Dilemma in New York State," Energy Policy 1: 243-253, December 1973.

23. D. Nelkin, "The Role of Experts in a Nuclear Siting Controversy, "Bulletin of Atomic Scientists, pp. 26-29, November 1974.

24. J. G. Mitchell, "The Selling of the Shelf," Audubon 77: 44-63, May 1975.

25. B. Gilbert, "The Devaluation of Alaska," Audubon 77: 64-80, May 1975.

26. A. M. Josephy, Jr., "Kaiparowitts: The Ultimate Obscenity," Audubon 78(2): 64-90, March 1976.

27. B. A. Bishop, "Public Participation in Water Resources Planning," IWR Report No. 70-7, Institute of Water Resources, Army Corps of Engineers, December 1970. 
28. T. E. Borton and K. P. Warner, "Involving Citizens in Water-Resources Planning," Environment and Behavior 3: 284-306, September 1971.

29. A. G. Onibokun and M. G. Curry, "An Ideology of Citizen Participation: The Metropolitan Seattle Transit Case Study, "Public Administration Review, 1976, pp. 269-277.

30. T. LaPorte and D. Metiay, "Public Attitudes Toward Present and Future Technologies: Satisfactions and Apprehensions," Social Studies of Science $\underline{5}$ : 373-398, 1975.

31. R. F. Goodman and B. B. Clary, "Community Attitudes and Action in Response to Airport Noise," Environment and Behavior 8: 441-469, 1976.

32. T. A. Heberlein, "The Land Ethic Realized: Some Social Psychological Explanations for Changing Environmental Attitudes," Journal of Social Issues 28: 79-87, 1972. 
No. of

Copies

OFFSITE

A. A. Churm

ERDA Chicago Patent Group

9800 South Cass Avenue

Argonne, IL 60439

D. S. Ballantine

ERDA Division of Biomedical and Environmental Research

Washington, DC 20545

R. P. Blaunstein

ERDA Division of Biomedical and Environmental Research

Washington, DC 20545

W. W. Burr

ERDA Division of Biomedical and Environmental Research

Washington, DC 20545

R. L. Butenhoff

ERDA Division of Biomedical and Environmental Research

Washington, DC 20545

C. E. Carter

ERDA Division of Biomedical and Environmental Research

Washington, DC 20545

C. W. Edington

ERDA Division of Biomedical and Environmental Research

Washington, DC 20545

W. O. Forster

ERDA Division of Biomedical and Environmental Research

Washington, DC 20545

G. J. Rotariu

ERDA Division of Biomedical and Environmental Research

Washington, OC 20545

D. H. Slade

ERDA Division of Biomedical and Environmental Research

Washington, DC 20545

J. Swinebroad

ERDA Division of Biomedical and Environmental Research

Washington, DC 20545

W. H. Weyzen

ERDA Division of Biomedical and Environmental Research Washington, DC 20545
No. of

Copies

R. W. Wood

ERDA Division of Biomedical and Environmental Research

Washington, DC 20545

W. E. Mott

ERDA Division of Environmental Control Technology

Washington, DC 20545

M. Reilly

ERDA Division of Fossil Energy

Washington, DC 20545

H. L. Hollister

Deputy Assistant Administrator for Environment and Safety

Washington, DC 20545

J. L. Liverman

ERDA Assistant Administrator for Environment and Safety

Washington, DC 20545

J. Coleman

ERDA Office of Environment Policy Analysis

Hashington, DC 20545

B. W. Wachholz

ERDA Office of Environmental Policy Analysis

Washington, DC 20545

E. S. Burton

ERDA Office of Planning, Analysis and Evaluation

Washington, DC 20545

N. F. Barr

ERDA Division of Technology Overview

Washington, DC 20545

W. G. Belter

ERDA Division of Technology Overview

Washington, DC 20545

R. D. Cooper

ERDA Division of Technology Overview

Washington, DC 20545

P. H. Gearhart

ERDA Division of Technology Overview

Washington, DC 20545

R. R. Newton

ERDA Division of Technology Overview

Washington, DC 20545

Distr-1
No. of

Copies

H. R. Wasson

ERDA Division of Technology Overview

Washington, DC 20545

A. B. Joseph

Office of Nuclear Regulatory Research

U.S. Nuclear Regulatory Commission

Washington, DC 20555

F. G. Lowman

Office of Nuclear Regulatory Research

U.S. Nuclear Regulatory Commission

Washington, DC 20555

E. E. Held

Office of Standards Development

U.S. Nuclear Regulatory Commission

Washington, DC 20555

ERDA Technical Information Center

J. B. Robertson

Federal Energy Administration

Room 1992

Federal Building

915 Second Avenue

Seattle, WA $98174^{\circ}$

L. E. Coate

U.S. Environmental Protection Agency, Region $X$

Seattle, WA 98101

E. Croke

Argonne National Laboratory

9700 South Cass Avenue

Argonne, IL 60439

L. J. Hoover

Argonne National Laboratory

9700 South Cass Avenue

Argonne, IL 60439

P. M. Meier

Bidg. 475

Brookhaven National Laboratory Upton, NY 11973

P. Palmedo

Bidg. 475

Brookhaven National Laboratory Upton, NY 11973

W. Siri

University of California - LBL Lawrence Berkeley Laboratory Berkeley, CA 94720 
No. of Copies

W. Robison

University of California- LLL

Lawrence Livermore Laboratory

P.0. Box 808 ...

Livermore, CA 94550

E. Hammi 1

Los Alamos Scientific

Laboratory

P.0. Box 1663

Los Alamos, NM 87545

R. Malenfant

Los Alamos Scientific

Laboratory

University of California

P.0. Box 1663

Los Alamos, NM 87545

S. J. Auerbach

Dak Ridge National

Laboratory

P.0. Box $X$

Oak Ridge TN 37830

W. Fulkerson

Oak Ridge National

Laboratory

P. 0. Box $X$

Oak Ridge, TN 37830

Col. Charles A. Debelius

District Engineer

Alaska District

Corps of Engineers

Anchorage, AK 99510

R. Estess

State Clearinghouse

Division of Policy

Development

and Planning

Office of the Governor

Pouch AD

Juneau, AK 99801

J. Lowell Jensen

Public Utilities Commission

1100 Mackay Building

338 Denali Street

Anchorage, AK 99501

W. C. McConkey, Director Division of Energy and Power Development

Department of Commerce and Economic Development

Mackay Building

338 Denali Street

Anchorage, AK 99501
No. of

Copies

G. Martin

Department of Natural

Resources

11 th Floor, State

Office Bidg.

Pouch $M$

Juneau, AK 99811

M. F. Thomas

Regional Engineer

Bureau of Power

555 Battery Street

Room 415

San Francisco, CA 94111

D. Guss

Bureau of State Planning and Community Affairs

State House

Boise, ID 83720

K. D. Smith

Public Utilities

Commission

$472 \mathrm{~W}$. Washington St.

Boise, ID 83720

R. J. Vissia

Regional Director

Pacific Northwest Region

(Columbia River Basin)

Federal Building,

U.S. Court House

$550 \mathrm{~W}$. Fort Street

Boise, ID 83724

R. N. Wise

Bureau of State Planning and Community Affairs

State House

Boise, ID 83720

R. Hulme

State Clearinghouse

Office of Budget and Program Planning

232 Capitol Building

Helena, MT 59601

M. O. Mortensen

Energy Advisory Council

$c / 0$ Lt. Governor's Office

Capitol Building

Helena, MT 59601

3. Nybo

Energy Advisory Council

$c / 0$ t. Governor's Office

Capitol Building

Helena, MT 59601

W. Opitz

Public Service Commission

1227 11th Avenue

Helena, MT 59601
No. of

Copies

\section{B. Roberts}

State Land Use

Planning Bureau

Department of Community

Affairs

Capitol Post Office

Helena, MT 59601

A. C. Tsao

Energy Planning Division

Department of Natural

Resources and Conservation

32 South Ewing

Helena, MT 59601

H. Brauner

Conservation and Development Commission

1175 Court Street N.E.

Salem, OR 97301

Charles Davis

Public Itility Commissioner

Labor and Industries Bldg.

Salem, OR 97310

Col. C. D. Gilkey

District Engineer

Portland District

Corps of Engineers

2850 S.E. 82nd Ave. (97266)

P.0. Box 2946

Portland, OR 97208

Maj. Gen. W. E. Peel

Division Engineer

North Pacific Division

Corps of Engineers

210 Custom House

Portland, OR 97209

F. D. Miller

Oregon Department of Energy

528 Cottage, N.E.

Salem, $O R \quad 97310$

Dr. K. Woods

Energy Facility Siting Division

Department of Energy

528 Cottage, N.E.

Salem, OR 97310

W. Young

Intergovernmental Relations Division

Office of the Governor

240 Cottage Street, S.E.

Salem, OR 97310 
No. of

Copies

F. S. Adair

Washington State Department of Commerce and Economic Development

Olympia, WA 98504

Col. N. P. Conover

District Engineer

Walla. Walla District

Corps of Engineers

Bldg. 502, City-County Airport

Walla Walla, WA 99362

Col. Raymond J. Eineigl

District Engineer

Seattle District

Corps of Engineers

1519 Alaskan Way South

Seattle, WA 98134

N. Lewis

Assistant Director

Office of Program Planning and Fiscal Management

State Planning Division

House Office Building

Olympia, WA 98504

R. Polson

Energy Facilities Site

Evaluation Council

820 East Fifth Avenue

Olympia, WA 98504

E. T. Shaw

Utilities and Transportation Commission

Highways-Licenses Building

Olympia, WA 98504

E. Adams, Director

Idaho Energy Office

State House

Boise, ID 83720

L. Bradley

Washington State Energy office

1000 Cherry

Olympia, WA 98504

M. Walsh

Department of Ecology

State of washington

0lympia, WA 98504

A. J. Eliopulos

Public Service Commission

Supreme Court Building

Cheyenne, WY 82002

D. B. Freudenthal

State Planning Coordinator's Office

Office of the Governor

State Capitol

Cheyenne, WY 82002
No. of

Copies

D. Hoffman

Mineral Development Division

Department of Economic

Planning and Development

720 West 18 th Street

Cheyenne, WY 82002

F. C. Blood

Bonneville Power

Administration

P.O. Box 3621

Portland, OR 97208

R. S. Gens

Bonneville Power

Administration

P.0. Box 3621

Portland, OR 97208

J. Hoozen

Bonneville Power

Administration

P.0. Box 3621

Portland, OR 97208

J. C. Loosli

Bonneville Power

Administration

P.0. Box 3621

Portland, OR 97208

C. M. Moore

Bonneville Power

Administration

P.0. Box 3621

Portland, OR 97208

M. Katz

Northwest Energy Policy Project

1096 Lioyd Building

700 N.E. Mul tnomah Street

Portland, OR 97232

R. Lewis

Northwest Energy Policy Project

1096 Lloyd Building

700 N.E. Multnomah Street

Portland, OR 97232

W. E. Bruner

Pacific Northwest Regional Commission

1205 Washington

Vancouver, WA 98660

D. J. Lane

Pacific Northwest River Basins Commission

1 Columbia River

P.0. Box 908

Vancouver, WA 98660

Or. 0. Osborne

Oregon State University

Electrical Engineering

Department

Corvallis, OR 97331

Distr-3
No. of

Copies

Dr. R. Wensink

Oregon State University

Agricultural Engineering

Department

Corvallis, OR 97331

Dr. J. Jaksch

Corvallis Environmental Research Laboratory

Corvall is Environmental

Protection Agency

Corvalitis, OR 97331

J. Brar

Washington State University

Pullman, WA 99163

G. Hinman

Washington State

University

Pullman, WA 99163

R. T. Miller

Vice President

Engineering and Gas Control

Nor thwest Natural Gas Company

123 N.W. Flanders Street

Portland, OR 97209

H. S. Johnson

Portland General Electric Co.

621 S.W. Alder Street

Portland, $O R \quad 97205$

G. A. Perrautt

Portland General Electric Co.

621 S.W. Alder Street

Portland, OR 97205

C. L. Sauvie

Portland General Electric Co.

621 S.W. Alder Street

Portland, OR 97205

J. L. Williams

Portland General Electric Co.

621 S.W. Alder Street

Portland, OR 97205

R. A. Duncan

Coordination Engineer

Northiwest Power Pool

920 S.W. 6th Ave., Rm. 1210

Portland, OR 97204

H. Kosmata

Washington Public Power Supply System

3000 George Washington Way

Richland, Wh 99352 
No. of

Copies

D. Renberger/G. F. Bailey Washington Public Power Supply System 3000 George Washington Way Richland, WA 99352

R. Tillson

Washington Public Power Supply Systern

3000 George Washington Way

Richland, WA 99352

R. Woodruff

Washington Public Power Supply System

3000 George Washington Way

Richland, WA 99352

D. N. Morris

The Rand Corporation

1700 Main Street

Santa Monica, CA 90406

J. W. Ell is

Puget Sound Power and Light Company

Puget Power Building

Bellevue, WA 98009

L. E. Hall

Puget Sound Power and Light Company

Puget Power Building

Bellevue, WA 98009

B. C. Thomas

Puget Sound Power and Light Company

Puget Power Building

Bellevue, WA 98009

T. E. Browne

Electric Power Research Institute

3412 Hillview Avenue

P.0. Box 10412

Palo Alto, CA 94304

R. Crow

Electric Power Research Institute

3412 Hillview Avenue

P.0. Box 10412

Palo Alto, CA 94304

M. Greenburger

Electric Power Research Institute

3412 Hillview Avenue

P.0. Box 10412

Palo Alto, CA 94304

L. Henning

Electric Power Research

Institute

3412 Hillview Avenue

P.0. Box 10412

Palo Alto, CA 94304
Ho. of

Copies

H. A. Kornberg

Electric Power Research Institute

3412 Hillview Avenue

P.0. Box 10412

Palo Alto, CA 94304

M. Searle

Electric Power Research Institute

$3412 \mathrm{Hillview} \mathrm{Avenue}$

P.0. Box 10412

Palo Alto, CA 94304

S. Boris

Teknekron Corp.

2118 Miluia Street

Berkeley, CA 94704

J. W. LaFond

City of Seattle

Department of Lighting

1015 Third Avenue

Seattle, WA 98104

R. Sheehan

City of Seattle

Department of Lighting

1015 Third Avenue

Seattle, WA 98104

J. McFadden

Energy Inc.

Box 736

Idaho Falls, ID 83401

K. Blackburn

old West Regional Commission

Fratt Building, Suite 306A

Billings, MT 59101

G. Culp

Culp, Dwyer, Guterson, and Grader

Hoge Building

Second and Cherry

Seattle, WA 98104

B. Goldharmer

Loyde Building

700 NE Multnomah

Portland, OR 97232

H. C. Elmore

Pacific Northwest Utilities Conference Comittee

P.0. Box 1231

Wenatchee, WA 98801

D. J. Lewis

Public Service Building

920 5.W. Sixth

Portland, OR 97204

R. A. Hofacker

Montana Power Company

40 East Broadway

Butte, MT 59701
No. of

Copies

R. H. Bendio

Idaho Power Company

P.0. Box 70

Boise, ID 8372 ]

H. W. Harding

Washington Water Power Company

P.0. Box 3727

Spokane, WA 99220

H. G. Curtis

Public Power Council

P.0. Box 1307

Vancouver, WA 98660

Scott Alstrom

Western States Water CounciT

220 South Second East, Suite 200

Salt Lake City, UT 84111

J. T. Stiles

Pacific Power and Light

Portland, OR 97204

W. Rogers, Jr.

Western Interstate Nuclear Board

P.0. Box 15038

Lakewood, CO 80215

L. Harris

Western Aluminum Producers

Association

P.0. Box 8484

Portland, OR 97207

W. L. Guy

Western Governors' Regional

Energy Policy Office

4730 Oakland St.

Denver, CO 80239

K. Muller

Northern Plains Resource Council

418 Stapleton Building

Billings, MT 59101

J. Binanado

Regional Planner

Bureau of Land Maragement

P.O. Box 30157

Billings, MT 59107

W. Toml inson

Environmental Library

Rn 208A Natural Sciences

University of Montana

Missoula, MT 59801

R. Doell

U.S. Geological Survey

354 Middlefield Road

Menlo Park, CA 94025 
No. of

Copies

B. Pearson
RIS Library
Department of Ecology
Olympia, WA 98504

M. Neville

Idaho Legislative Council

State. House

Boise, ID 83702

P. H. Rose, Pres.

Mathematical Sciences

Northwest, Inc.

P.0. Box 1887

Bellevue, WA 98009

W. C. Wo1kenhauer Washington Public Power Supply System

Richland, WA 99352

F. Claggett

Office of Community Development

State of Washington

400 Capitol Center Building

Olympia, WA 98504

Battel Te-Northwest

Human Affairs Research Center (HARC)
M. G. Curry (5)
M. Green (5)
J. A. Hebert
S. M. Nealey
M. Mertaugh
D. J. Merwin
M. E. $01 \operatorname{sen}(5)$
R. E. Schuller

ONSITE

4 ERDA Richland Operations Office

P. W. Gottschalk

G. L. Liffick

R. H. Lindsey

B. J. Melton
No. of

Copies

92 Battelie-Northwest

W. J. Bair

C. H. Bloomster

J. B. Burnham (10)

D. B. Cearlock

L. L. Clark

M. Clement

B. W. Cone

J. W. Currie

D. E. Deonigi

P. J. Dionne

D. W. Dragnich

D. L. Elliott

L. E. Erickson

D. W. Fraley

T. J. Foley

J. C. Fox

T. P. Harrington (10)

P. L. Hendrickson

D. Hessel

J. J. Jacobsen (10)

J. King

C. A. Knutsen

T. P. Kula

J. W. Litchfield

K. A. McGinnis

S. Marks

W. A. Reardon

D. S. Renne

W. H. Rickard

R. H. Sauer

L. C. Schmid

S. J. Shupe

P. J. Snorek

H. H. Swift

W. L. Templeton

D. W. Uresk

B. E. Vaughan

R. D. Widrig

G. L. Wilfert

K. E. Yandon

J. R. Young

Economics Library (20)

Technical Information Files (3)

Technical Publications 